\title{
ISOLASI DAN SELEKSI BAKTERI PROBIOTIK DARI LINGKUNGAN TAMBAK DAN HATCHERI UNTUK PENGENDALIAN PENYAKIT VIBRIOSIS PADA LARVA UDANG WINDU, Penaeus monodon
}

\author{
Widanarni, Fahmi Rajab, Sukenda, dan Mia Setiawati \\ Departemen Budidaya Perairan-FPIK, Institut Pertanian Bogor \\ Jl. Lingkar Akademik, Kampus IPB Darmaga, Bogor 16680 \\ E-mail: widanarni@yahoo.com
}

(Naskah diterima: 15 Oktober 2008; Disetujui publikasi: 26 April 2010)

\begin{abstract}
ABSTRAK
Penelitian ini bertujuan untuk memperoleh bakteri probiotik yang mampu menghambat pertumbuhan Vibrio harveyi untuk pengendalian penyakit vibriosis pada larva udang windu. Jumlah isolat bakteri yang berhasil diisolasi dari 34 sumber yang berbeda di lingkungan tambak dan hatcheri ada 118 isolat. Dari total isolat tersebut setelah diseleksi secara in vitro menggunakan metode Kirby-Bauer dipilih 3 isolat bakteri kandidat probiotik yang paling potensial dalam menghambat pertumbuhan bakteri $V$. harveyi MR5339, yaitu isolat 9a berasal dari Cyclotella dengan zona hambat 12,8 mm; isolat Ua berasal dari saluran pencernaan udang vaname dengan zona hambat 14,5 $\mathrm{mm}$; dan isolat $\mathrm{P}_{17} \mathrm{~B}_{\mathrm{b}}$ berasal dari air pemeliharaan kerapu bebek dengan zona hambat $15,0 \mathrm{~mm}$. Hasil uji patogenisitas dengan konsentrasi bakteri $10^{6} \mathrm{CFU} / \mathrm{mL}$ menunjukkan bahwa ketiga isolat tersebut tidak bersifat patogen pada larva udang windu. Hasil uji tantang pada larva udang juga menunjukkan bahwa ketiga isolat tersebut mampu meningkatkan sintasan larva udang windu. Nilai sintasan larva pada perlakuan yang selain diinfeksi dengan $V$. harveyi MR5339 juga ditambah probiotik $\mathrm{Ua}, 9 \mathrm{a}$, dan $\mathrm{P}_{17} \mathrm{~B}_{\mathrm{b}}$ masing-masing adalah $88,3 \% ; 88,3 \%$; dan $76,7 \%$ sedangkan pada perlakuan yang hanya diinfeksi dengan $V$. harveyi MR5339 tanpa probiotik nilai sintasannya hanya mencapai $65,0 \%$. Populasi $V$. harveyi pada perlakuan dengan penambahan bakteri probiotik tampak lebih rendah dibanding perlakuan tanpa probiotik, hal ini menunjukkan kemungkinan adanya kompetisi antara bakteri $V$. harveyi dengan bakteri probiotik.
\end{abstract}

KATA KUNCI: bakteri probiotik, vibriosis, udang windu, hatcheri, tambak

ABSTRACT: Isolation and selection of probiotic bacteria from pond and hatchery to control vibriosis on tiger shrimp larvae, Penaeus monodon. By: Widanarni, Fahmi Rajab, Sukenda, and Mia Setiawati

This research was performed to obtain probiotic bacteria that were able to inhibit the growth of Vibrio harveyi to control vibriosis on tiger shrimp larvae. Number of isolates from 34 different sources in different shrimp ponds and hatcheries were 118 isolates. Of the total isolates, after in vitro selection using Kirby-Bauer method, there were three bacteria isolates found to be the most potential bacteria candidate for inhibiting the growth of $\boldsymbol{V}$. harveyi MR 5339 bacteria, they were $9 a$ isolate from Cyclotella origin with inhibition zone of $12.8 \mathrm{~mm}, U_{a}$ isolate from white shrimp intestinal tract with inhibition zone of $14.5 \mathrm{~mm}$, and $P_{17} B_{b}$ isolate from polka dot grouper rearing water with inhibition zone of $15.0 \mathrm{~mm}$. Pathogenicity test result at concentration of $10^{6} \mathrm{CFU} / \mathrm{mL}$ bacteria showed that the three isolates were not pathogenic to tiger shrimp larva. Challenge test results on shrimp larva also showed that the three isolates could increase survival rate of tiger shrimp larva. Survival rate values in 
infection treatment using $V$. harveyi MR5339 with Ua, 9a, and $P_{17} B_{b}$ bacteria were $88.3 \%, 88.3 \%$, and $76.7 \%$, respectively; whereas infection treatment merely using $V$. harveyi MR5339 without the probiotic gave $65.0 \%$ survival rate. V. harveyi populations in treatment by addition of the probiotic bacteria were lower than that of treatment without probiotic bacteria. This fact suggests that there is a possible competition between $\boldsymbol{V}$. harveyi and the tested probiotic bacteria.

KEYWORDS: probiotic bacteria, vibriosis, Penaeus monodon, pond, hatchery

\section{PENDAHULUAN}

Serangan penyakit bakterial pada tingkat pembenihan yang paling serius dan sering menyebabkan terjadinya kematian massal pada larva udang windu adalah serangan bakteri berpendar yang diidentifikasi sebagai Vibrio harveyi (Lavilla-Pitogo et al., 1990; Karunasagar et al., 1994; Ruangpan et al., 1998). Bakteri ini pada umumnya menyerang larva udang pada stadia zoea, mysis dan awal pascalarva (Lavilla-Pitogo et al., 1990) sehingga merupakan kendala dalam penyediaan benih udang yang sehat dalam jumlah besar yang diperlukan untuk produksi udang.

Usaha untuk menanggulangi penyakit tersebut telah dilakukan dengan menggunakan berbagai jenis antibiotik. Namun penggunaan antibiotik secara terus-menerus dengan dosis sub-optimal telah mengakibatkan $V$. harveyi menjadi resisten (Karunasagar et al., 1994; Tjahjadi et al., 1994; Teo et al., 2000). Penggunaan vaksin juga sulit diterapkan karena galur $V$. harveyi yang menyerang larva udang sangat bervariasi (Suwanto et al., 1998). Selain itu, degradasi vaksin yang diserap merupakan masalah lain di samping beragamnya galur $V$. harveyi patogen (Alabi et al., 1999).

Dengan adanya kelemahan-kelemahan dari berbagai upaya yang telah dilakukan, penggunaan bakteri probiotik sebagai agen biokontrol pada pembenihan udang menawarkan alternatif pemecahan untuk menanggulangi permasalahan tersebut. Dasar pendekatan ini adalah dengan menggunakan aktivitas mikroorganisme yang dapat menekan atau menghambat pertumbuhan $V$. harveyi tanpa menimbulkan dampak buruk terhadap sistem keseimbangan ekologis mikrob. Cara ini telah terbukti berhasil dan banyak digunakan pada usaha hewan ternak (Fuller, 1992; Ohhira et al., 1996), dan akhir-akhir ini mulai diteliti serta diaplikasikan pada sistem budidaya perairan, misalnya pada budidaya ikan (Skjermo \& Vadstein 1999; Gram et al.,
1999), kekerangan (Douillet \& Langdon 1994; Riquelme et al., 1997), dan udang (Tjahyadi et al., 1994; Rengpipat et al., 1998a, 1998b, 2000; Gomez-Gil et al., 2000).

Penelitian ini bertujuan untuk mendapatkan isolat lokal bakteri probiotik yang secara in vitro maupun in vivo mampu menghambat pertumbuhan $V$. harveyi patogen serta efektif diaplikasikan dalam penanggulangan penyakit vibriosis di Indonesia.

\section{METODE PENELITIAN}

\section{Isolasi Bakteri Kandidat Probiotik}

Bakteri kandidat probiotik diisolasi dari berbagai lingkungan tambak dan hatcheri yaitu di Balai Pengembangan Benih Ikan Laut Payau dan Udang (BPBILAPU), Pangandaran, Jawa Barat serta hatcheri udang PT Biru Laut Khatulistiwa dan tambak udang intensif di Lampung. Sampel yang diambil meliputi: berbagai stadia larva udang dan media pemeliharaannya serta pakan alami larva udang berupa kultur alga dan artemia. Masing-masing sampel disebar pada media seawatercomplete (SWC)-agar ( $5 \mathrm{~g}$ bactopeptone, $1 \mathrm{~g}$ yeast extract, $3 \mathrm{~mL}$ glycerol, $15 \mathrm{~g}$ agar, $750 \mathrm{~mL}$ air laut, dan $250 \mathrm{~mL}$ aquades) dan selanjutnya diinkubasi pada suhu ruang $28^{\circ} \mathrm{C}-31^{\circ} \mathrm{C}$ selama 24 jam. Koloni yang terpisah kemudian dipilih secara acak untuk mendapatkan isolat murni untuk dipelajari lebih lanjut.

V. harveyiyang digunakan dalam penelitian ini adalah V. harveyi MR5339, yang diisolasi dari udang sakit dan merupakan koleksi dari Balai Riset Perikanan Budidaya Air Payau, Maros, Sulawesi Selatan dan telah diuji bersifat patogen pada larva udang windu.

\section{Pengujian In Vitro Bakteri Kandidat Probiotik}

Semua isolat murni yang diperoleh diuji daya hambatnya terhadap V. harveyi MR5339 secara in vitro dengan metode Kirby-Bauer, yakni dengan mengamati diameter zona 
hambat pada media SWC-agar. Bakteri kandidat probiotik dan $V$. harveyi MR5339 masingmasing sebanyak 1 ose disuspensikan ke dalam $500 \mu \mathrm{L}$ larutan fisiologis ( $\mathrm{NaCl} 0,85 \%)$ steril di dalam tabung eppendorf. Selanjutnya sebanyak $50 \mu \mathrm{L}$ suspensi $V$. harveyi MR5339 disebar pada media SWC-agar dan dibiarkan sampai agak kering. Paper disk steril merk Whatman nomor 42 dengan diameter $5 \mathrm{~mm}$ diletakkan di atas media SWC-agar yang telah diberi $V$. harveyi MR5339 dan kemudian sebanyak $5 \mu \mathrm{L}$ suspensi bakteri kandidat probiotik diteteskan di atas paper disk. Uji ini dilakukan dengan 4 ulangan dan 1 kontrol (larutan fisiologis). Setelah inkubasi pada suhu ruang selama 24 jam, zona hambat diukur dan nilainya dirata-ratakan.

\section{Patogenisitas Bakteri Kandidat Probiotik}

Sebelum dilakukan uji tantang dengan $V$. harveyi pada larva udang, tiga isolat yang paling potensial berdasarkan uji in vitro diuji patogenisitasnya pada larva udang. Pengujian dilakukan dengan menambahkan suspensi isolat bakteri kandidat probiotik dengan konsentrasi $10^{6} \mathrm{CFU} / \mathrm{mL}$ pada media pemeliharaan larva udang. Pasca larva udang windu stadia $\mathrm{PL}_{1}$ dipelihara dalam toples yang diisi air laut steril 2 liter dengan kepadatan 10 ekor/L dan diberi pakan Artemia 3-5 individu/ $\mathrm{mL}$ dengan frekwensi 4 kali/hari. Ganti air dan penyiponan dilakukan setiap hari sebanyak $10 \%$ dari volume total wadah pemeliharaan. Pemeliharaan pasca larva udang dilakukan selama 5 hari dan larva yang mati dihitung setiap hari. Pada akhir percobaan dihitung sintasan larva dan dibandingkan dengan kontrol, yakni perlakuan tanpa penambahan isolat bakteri kandidat probiotik.

\section{Uji Tantang Bakteri Kandidat Probiotik dengan V. harveyi MR5339} pada Larva Udang Windu

Tiga isolat bakteri kandidat probiotik yang paling potensial berdasarkan uji in vitro dan tidak bersifat patogen, diuji efektivitasnya dalam menghambat serangan $V$. harveyi pada larva udang. Isolat bakteri kandidat probiotik dengan konsentrasi $10^{6} \mathrm{CFU} / \mathrm{mL}$ dimasukkan ke dalam wadah pemeliharaan udang sehari setelah larva udang dimasukkan. Pasca larva udang windu stadia $\mathrm{PL}_{1}$ dipelihara dalam toples yang diisi air laut steril 2 liter dengan kepadatan 10 ekor/L. Setelah kokultivasi dengan pasca larva udang selama 6 jam, V. harveyi MR5339 dimasukkan dengan konsentrasi $10^{6} \mathrm{CFU} / \mathrm{mL}$ $\left(\mathrm{LD}_{50}\right)$. Percobaan dilakukan dengan tiga ulangan termasuk kontrol (tanpa penambahan $V$. harveyi maupun isolat probiotik). Selama percobaan, pasca larva udang diberi pakan Artemia sebanyak 3-5 individu/mL dengan frekuensi 4 kali sehari. Ganti air dan penyiponan dilakukan setiap hari sebanyak $10 \%$ dari volume total wadah pemeliharaan. Pengamatan dilakukan selama 5 hari, dan pada akhir percobaan dihitung sintasan dan pertumbuhan pasca larva udang. Sintasan pasca larva udang dihitung menggunakan rumus Effendie (1979):

$$
\mathrm{SR}=\frac{\mathrm{Nt}}{\mathrm{No}} \times 100 \%
$$

di mana:

SR : Tingkat sintasan/Survival rate (\%)

$\mathrm{Nt}$ : Jumlah udang yang hidup pada akhir perlakuan (ekor)/Number of survived shrimps (ind.)

No: Jumlah udang yang hidup pada awal perlakuan (ekor)/Number of shrimps at the beginning of the experiment (ind.)

Pertumbuhan larva udang dihitung berdasarkan pertambahan bobot dan panjang, dengan rumus Huisman (1987):

$\alpha=\left\{\left[\sqrt[t]{\frac{W t}{W o}-1}\right] \times 100 \%\right\}$ dan $\alpha=\left\{\left[\sqrt[t]{\frac{L t}{L o}}-1\right] \times 100 \%\right\}$

di mana:

$\alpha \quad$ : Laju pertumbuhan panjang atau bobot udang Specific length and weight growth rates (\%)

t : Lama waktu pemeliharaan udang (hari) Period of culture (day)

Wt : Bobot rata-rata akhir udang/Average shrimp final body weight (mg)

Wo : Bobot rata-rata awal udang/Average shrimp initial body weight $(\mathrm{mg})$

Lt : Panjang rata-rata akhir udang/Average final body length $(\mathrm{mm})$

Lo : Panjang rata-rata awal udang/Average initial body length $(\mathrm{mm})$

\section{HASIL DAN BAHASAN}

\section{Isolat Bakteri Kandidat Probiotik}

Bakteri kandidat probiotik yang berhasil diisolasi dari 34 sumber yang berbeda di lingkungan tambak dan hatcheri ada 118 isolat. Dari 118 isolat tersebut, 22 isolat berasal dari 
tambak pembesaran udang vaname di Desa Pinang Gading, Kalianda, Lampung Selatan, 57 isolat dari lingkungan pembenihan udang PT Biru Laut Khatulistiwa, Lampung Selatan, dan 39 isolat dari Balai Pengembangan Benih Ikan Laut Payau dan Udang (BPBILAPU) Pangandaran, Jawa Barat.

Penampilan koloni isolat-isolat tersebut pada media SWC-agar ada beberapa macam. Warna koloni terdiri dari krem, kuning, oranye, dan putih dengan bentuk koloni oval, bulat kecil, bulat besar, dan beberapa menyebar (swarming). Beberapa koloni bakteri dari golongan Vibrio menampilkan warna kuning dan hijau pada media selektif Vibrio Thiosulphate Citrate Bile-Salt Sucrose (TCBSagar, Oxoid).

\section{Hasil Uji In Vitro Bakteri Kandidat Probiotik}

Hasil penapisan in vitro terhadap 118 isolat bakteri kandidat probiotik dalam menghambat pertumbuhan V. harveyi 5339 , diperoleh 62 isolat atau sebanyak 52,54\% yang menghasilkan zona hambat. Berdasarkan diameter zona hambat, golongan bakteri (Vibrio dan non-Vibrio), serta asal bakteri dipilih 3 isolat yaitu isolat 9a yang berasal dari alga Cyclotella dengan zona hambat $12,8 \mathrm{~mm}$; isolat $\mathrm{U}_{\mathrm{a}}$ yang berasal dari saluran pencernaan udang vaname dengan zona hambat $14,5 \mathrm{~mm}$; dan isolat $\mathrm{P}_{17} \mathrm{~B}_{\mathrm{b}}$ yang berasal dari air pemeliharaan kerapu bebek dengan zona hambat 15,0 mm. Isolat $A_{7}$ dengan zona hambat 14,6 mm dan $A_{4}$ dengan zona hambat $16,5 \mathrm{~mm}$ tidak dipilih karena kedua isolat tersebut merupakan jenis Vibrio dengan koloni hijau pada media TCBS (sebagaimana $V$. harveyi), sehingga dikhawatirkan bersifat patogen terhadap udang. Beberapa jenis Vibrio dengan koloni warna hijau seperti $V$. harveyi, $V$. parahaemolyticus, V. Anguillarum, dan $V$. vulnificus telah diketahui bersifat patogen terhadap ikan atau udang.

Muliani et al. (2003) mengisolasi sedikitnya 603 isolat bakteri asal laut dan 15 diantaranya $(2,5 \%)$ potensial menghambat $V$. harveyi MR5339. Haryanti et al. (2000) juga telah mengisolasi 273 isolat bakteri dan 3 di antaranya (1\%) menunjukkan adanya hambatan terhadap pertumbuhan $V$. harveyi secara in vitro. Hasil penelitian Riquelme et al. (1997) menunjukkan bahwa dari 57 isolat bakteri yang diisolasi dari air laut, 3 di antaranya (5\%) potensial menghambat pertumbuhan $V$. anguillarum. Adanya penghambatan pertumbuhan bakteri tidak selalu dapat diamati dengan melihat adanya zona bening pada media padat. Komposisi media yang digunakan mungkin mempengaruhi jumlah senyawa antimikrob yang dihasilkan atau dilepaskan ke media. Selain itu, penghambatan pertumbuhan tidak selalu berkaitan dengan produksi senyawa antimikrob seperti antibiotik, tetapi dapat juga karena adanya senyawa metabolit primer atau adanya perubahan $\mathrm{pH}$ (Verschuere et al., 2000). Isolat SVl yang tidak memperlihatkan adanya zona penghambatan pada uji in vitro ternyata dapat meningkatkan sintasan kekerangan pada uji in vivo (Riquelme et al., 1997).

\section{Patogenisitas Bakteri Kandidat Probiotik}

Sebelum dilakukan uji tantang dengan $V$. harveyi MR5339 pada larva udang, 3 isolat terbaik berdasarkan uji in vitro diuji patogenisitasnya terhadap pasca larva udang windu. Dari hasil uji patogenisitas terlihat bahwa nilai sintasan pada perlakuan dengan penambahan bakteri kandidat probiotik tidak berbeda nyata dengan kontrol (Gambar 1), artinya semua kandidat probiotik yang diuji tidak bersifat patogen terhadap pasca larva udang windu.

\section{Uji Tantang Bakteri Kandidat Probiotik dengan V. harveyi MR5339 pada Larva Udang Windu}

Tiga isolat bakteri kandidat probiotik yang paling potensial berdasarkan uji in vitro, diuji efektivitasnya dalam menghambat serangan V. harveyi MR5339 pada pasca larva udang windu. Hasil pengujian menunjukkan bahwa isolat $U_{a}$ dan 9 secara nyata $(P<0,05)$ dapat meningkatkan sintasan pasca larva udang (Gambar 2). Nilai sintasan pasca larva udang pada perlakuan yang selain diinfeksi $V$. harveyi MR5339 juga ditambahkan isolat Ua dan 9a adalah masing-masing 88,33\%; berbeda nyata $(\mathrm{P}<0,05)$ dengan kontrol positif (hanya diinfeksi $V$. harveyi MR5339) yang hanya mencapai 65\%.

Peningkatan nilai sintasan larva tersebut diduga karena adanya penghambatan pertumbuhan $V$. harveyi pada larva udang oleh bakteri probiotik. Hal ini dapat diketahui dari pengamatan populasi Vibrio pada media pemeliharaan dan kematian larva yang umumnya pada perlakuan dengan penambahan 


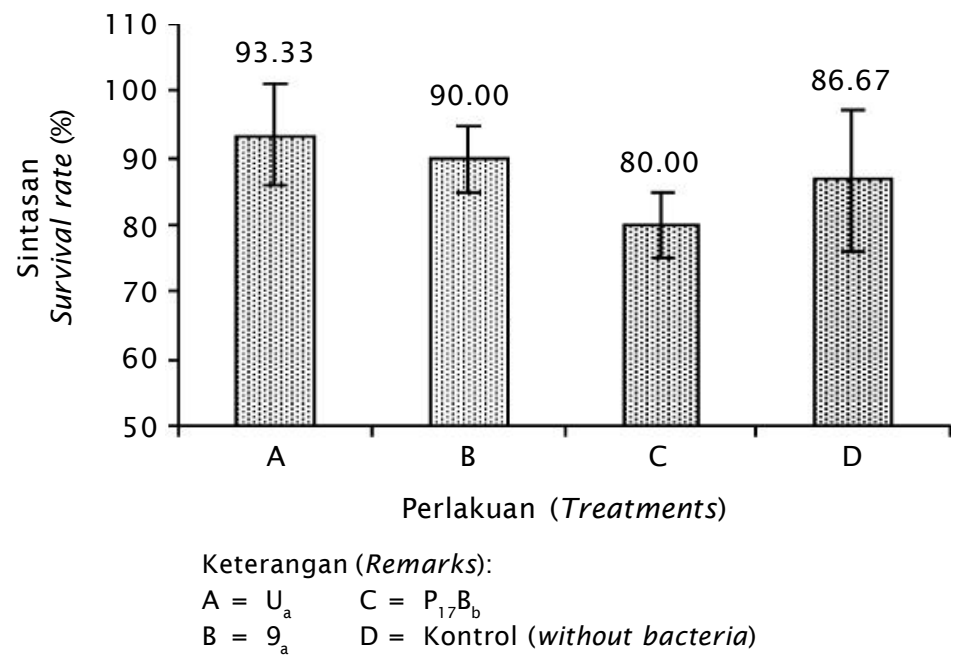

Gambar 1. Sintasan larva udang windu pada uji patogenisitas bakteri kandidat probiotik

Figure 1. Survival rate of tiger shrimp larva after pathogenicity test using probiotic bacteria candidates

probiotik lebih rendah dibanding kontrol positif (Gambar 3 dan 4).

Hasil penelitian Rengpipat et al. (1998b) menggunakan probiotik Bacillus S 11 menunjukkan bahwa setelah diberi perlakuan probiotik selama 100 hari dan kemudian diuji tantang dengan $V$. harveyi selama 10 hari, nilai sintasan udang windu mencapai $100 \%$ sedangkan pada kontrol $26 \%$. Haryanti et al. (2000) melaporkan bahwa penambahan bakteri

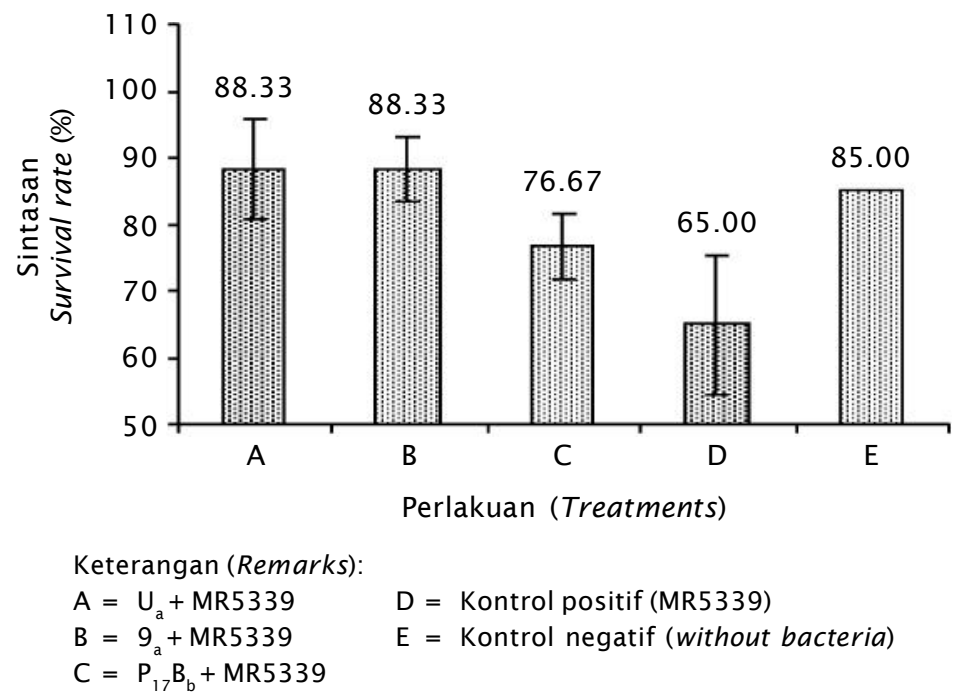

Gambar 2. Sintasan larva udang windu pada uji tantang bakteri kandidat probiotik dengan V. harveyi MR5339

Figure 2. Survival rate of tiger shrimp larva after challenge test to V. harveyi MR5339 with probiotic bacteria candidates 

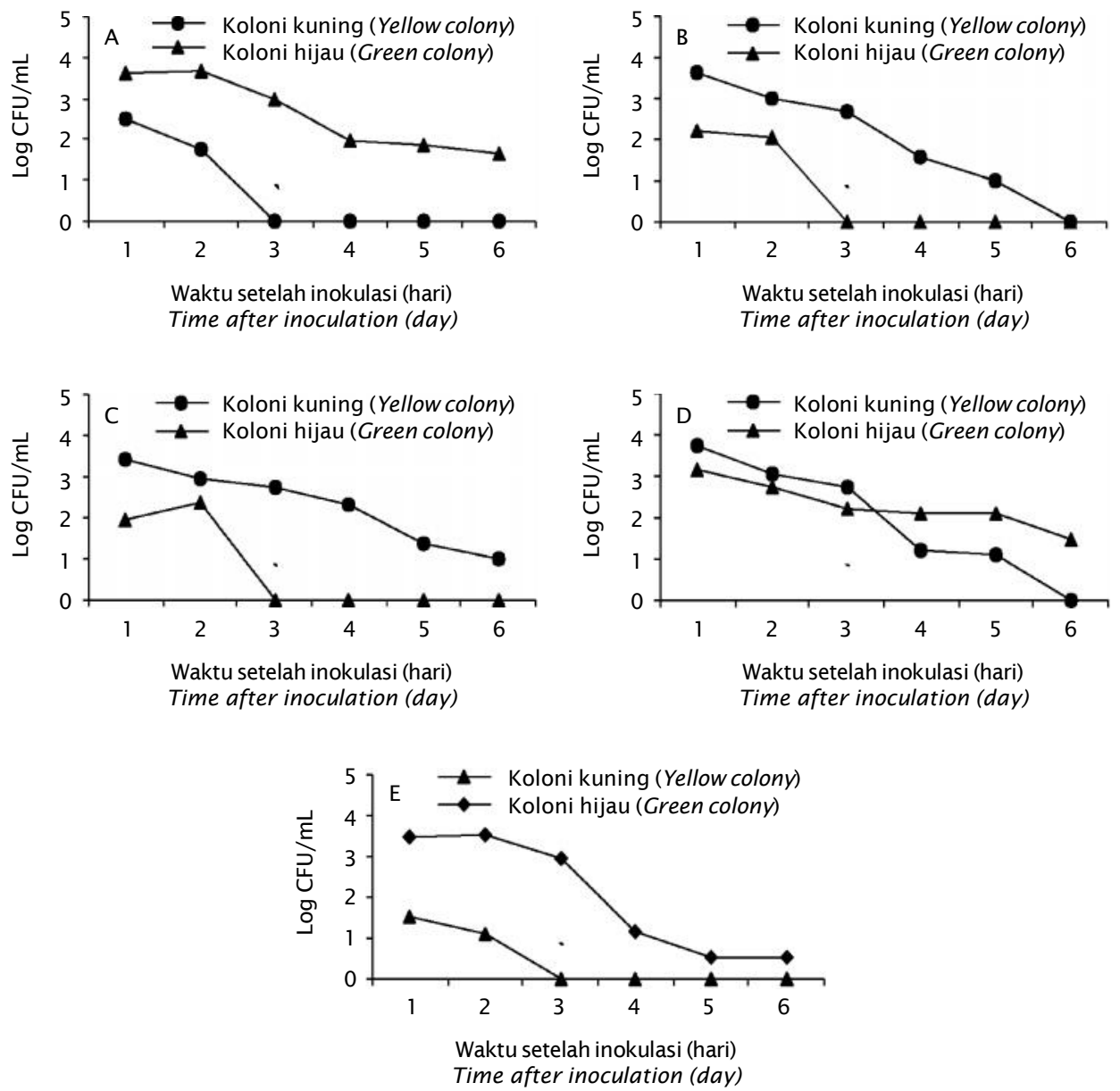

Keterangan (Remarks):
$A=U_{a}+$ MR5339
$\mathrm{D}=$ Kontrol positif (MR5339)
$B=9+M R 5339$
$\mathrm{E}=$ Kontrol negatif (without bacteria)
$C=P_{17} B_{b}+M R 5339$

Gambar 3. Jumlah sel Vibrio pada air media pemeliharaan larva udang selama uji tantang bakteri kandidat probiotik dengan V. harveyi MR5339

Figure 3. Number of Vibrio cells in rearing media of tiger shrimp larva during challenge test to V. harveyi MR5339 with probiotic bacteria candidates

strain By-9 dengan konsentrasi $10^{6} \mathrm{CFU} / \mathrm{mL}$ pada media pemeliharaan larva udang windu menghasilkan tingkat sintasan 59,3\%; sedangkan pada kontrol 14,7\%. Riquelme et al. (1997) juga melaporkan bahwa penambahan bakteri strain C30 dan SV1 pada media pemeliharaan larva kerang (Argopecten pururatus) secara nyata dapat meningkatkan sintasan larva tersebut walaupun tidak berpengaruh setelah diuji tantang dengan $V$. anguillarum. Dalam uji in vitro sebelumnya, isolat C30 diketahui dapat menghambat pertumbuhan $V$. anguillarum patogen, sedangkan SV1 tidak menunjukkan adanya penghambatan.

Laju pertumbuhan panjang larva udang windu pada perlakuan dengan penambahan probiotik berkisar antara 3,80-4,83\%; tidak berbeda nyata dengan kontrol positif 3,34\% dan kontrol negatif 4,66\% (Gambar 5). Demikian 

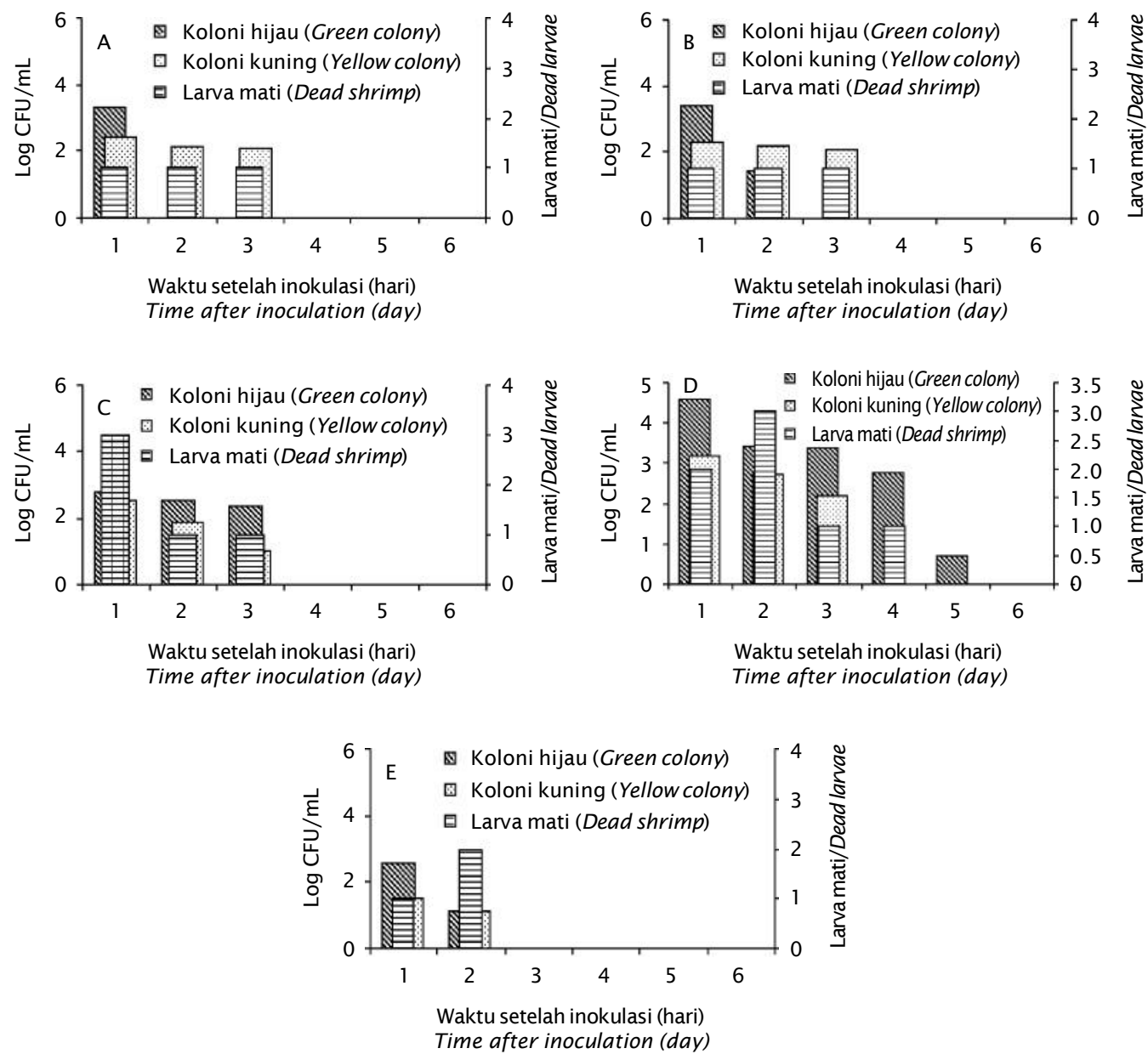

Keterangan (Remarks):

$$
\begin{array}{ll}
A=U_{a}+M R 5339 & D=\text { Kontrol positif (MR5339) } \\
B=9_{a}+\text { MR5339 } & E=\text { Kontrol negatif (without bacteria) } \\
C=P_{17} B_{b}+\text { MR5339 } &
\end{array}
$$

Gambar 4. Jumlah sel Vibrio pada larva udang mati selama uji tantang bakteri kandidat probiotik dengan V. harveyi MR5339

Figure 4. Number of Vibrio cells in dead tiger shrimp larva during challenge test to V. harveyi MR5339 with probiotic bacteria candidates

juga pada laju pertumbuhan bobot, pada perlakuan dengan penambahan probiotik laju pertumbuhan bobotnya berkisar antara 16,59\%-18,62\% tidak berbeda nyata dengan kontrol positif $14,81 \%$ dan kontrol negatif 17,08\% (Gambar 6). Hal ini menunjukkan bahwa probiotik yang diberikan mampu menghambat pertumbuhan $V$. harveyi sehingga dapat meningkatkan sintasan larva udang, namun belum dapat meningkatkan pertumbuhannya.

\section{Kualitas Air}

Pengukuran kualitas air dilakukan pada awal dan akhir penelitian dan hasilnya disajikan pada Tabel 1. Suhu air dari awal hingga akhir pemeliharaan larva udang berkisar antara $28,5^{\circ} \mathrm{C}-29,5^{\circ} \mathrm{C}$. Suhu air pemeliharaan cenderung stabil selama penelitian, karena pada wadah pemeliharaan dilengkapi dengan heater yang diatur pada suhu $29^{\circ} \mathrm{C}$, dan fiber 


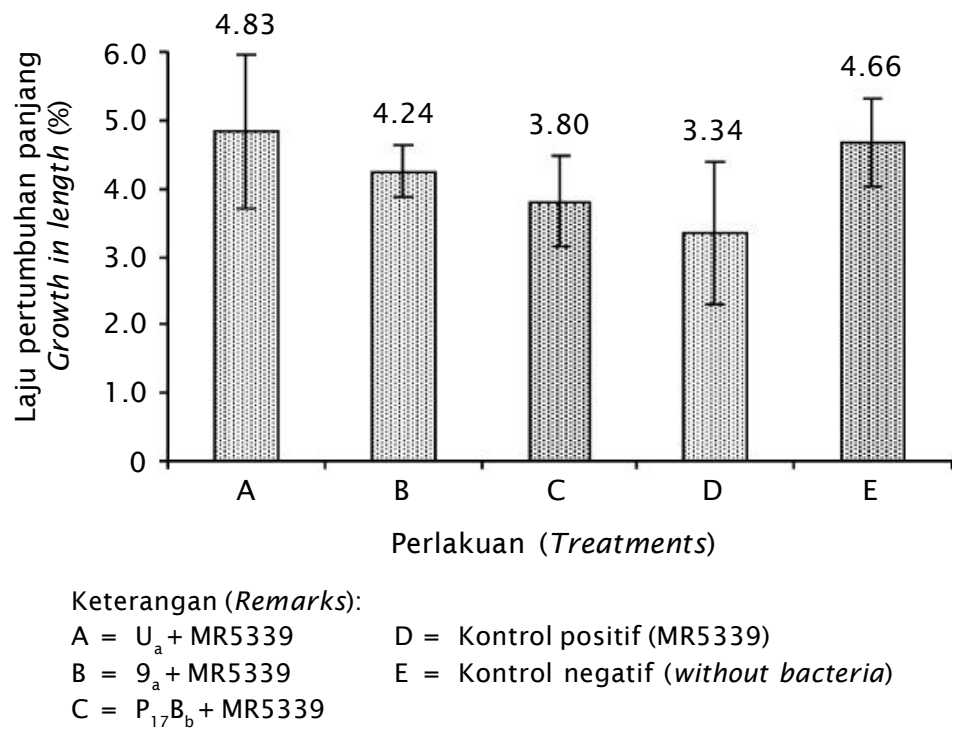

Gambar 5. Laju pertumbuhan panjang larva udang windu pada uji tantang bakteri kandidat probiotik dengan $V$. harveyi MR5339

Figure 5. Length growth rate of tiger shrimp larva after challenge test to $V$. harveyi MR5339 with probiotic bacteria candidates

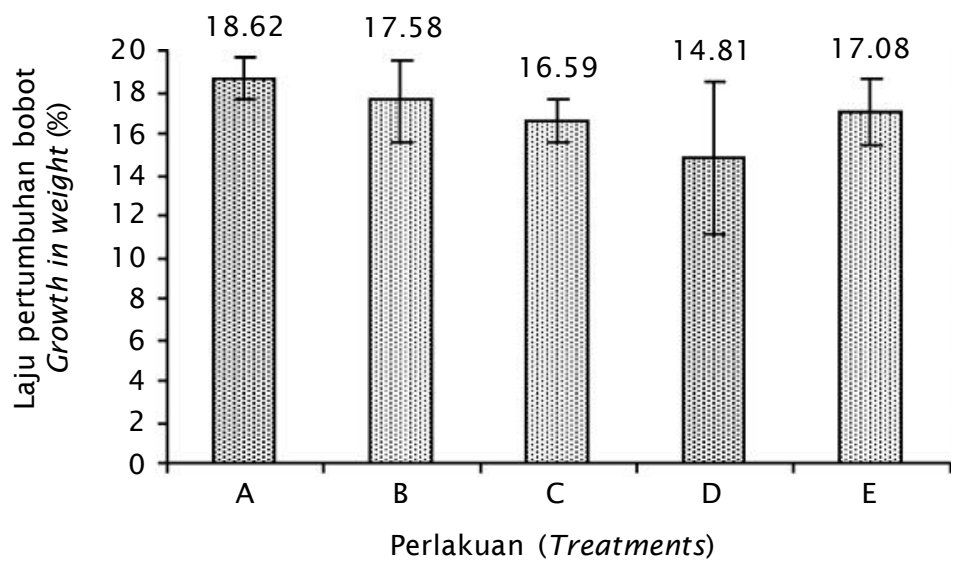

Keterangan (Remarks):

$$
\begin{array}{ll}
A=U_{a}+M R 5339 & D=\text { Kontrol positif (MR5339) } \\
B=9_{a}+\text { MR5339 } & E=\text { Kontrol negatif (without bacteria) } \\
C=P_{17} B_{b}+\text { MR5339 } &
\end{array}
$$

Gambar 6. Laju pertumbuhan bobot larva udang windu pada uji tantang bakteri kandidat probiotik dengan $V$. harveyi MR5339

Figure 6. Weight growth rate of tiger shrimp larva after challenge test to $V$. harveyi MR5339 with probiotic bacteria candidates 
Tabel 1. Parameter kualitas air media pemeliharaan udang selama penelitian

Table 1. Variation of water quality parameters during the experiment

\begin{tabular}{ccccccc}
\hline $\begin{array}{c}\text { Perlakuan } \\
\text { Treatments }\end{array}$ & $\begin{array}{c}\text { Semperature } \\
\left({ }^{\circ} \mathbf{C}\right)\end{array}$ & $\begin{array}{c}\text { DO } \\
(\mathbf{m g} / \mathrm{L})\end{array}$ & $\mathbf{p H}$ & $\begin{array}{c}\text { Salinitas } \\
\text { Salinity } \\
(\mathbf{p p t})\end{array}$ & $\begin{array}{c}\mathrm{NO}_{2} \\
(\mathbf{m g} / \mathrm{L})\end{array}$ & $\begin{array}{c}\mathrm{NH}_{3} \\
(\mathbf{m g} / \mathrm{L})\end{array}$ \\
\hline $\mathrm{A}$ & $28.5-29.5$ & $6.28-6.31$ & $7.99-8.04$ & $28-35$ & $0.62-2.42$ & $0.060-0.073$ \\
B & $28.5-29.5$ & $6.15-6.40$ & $8.01-8.09$ & $28-35$ & $0.47-2.51$ & $0.084-0.098$ \\
C & $28.5-29.5$ & $6.07-6.31$ & $8.05-8.10$ & $28-35$ & $0.63-2.53$ & $0.052-0.106$ \\
D & $28.5-29.5$ & $6.08-6.94$ & $7.99-8.08$ & $28-35$ & $0.15-2.51$ & $0.052-0.090$ \\
E & $28.5-29.5$ & $6.17-6.22$ & $8.02-8.03$ & $28-35$ & $0.39-2.49$ & $0.081-0.090$ \\
\hline
\end{tabular}

Keterangan (Remarks):

$$
\begin{array}{ll}
A=U_{a}+M R 5339 & D=\text { Kontrol positif (MR5339) } \\
B=9_{a}+\text { MR5339 } & E=\text { Kontrol negatif (without bacteria) } \\
C=P_{17} B_{b}+\text { MR5339 } &
\end{array}
$$

ditutup dengan plastik hitam, sehingga suhu pada pagi dan malam hari relatif stabil.

Salinitas air pemeliharaan pada awal penelitian untuk seluruh perlakuan adalah 28 ppt, sedangkan pada akhir penelitian adalah 35 ppt. Menurut Boyd (1990), larva udang sebaiknya dipelihara dalam air yang bersalinitas 28-35 ppt. Salinitas dapat mempengaruhi pertumbuhan karena terkait dengan osmoregulasi. Jika salinitas terlalu rendah atau terlalu tinggi akan menyebabkan banyak energi terpakai untuk osmoregulasi.

Nilai $\mathrm{pH}$ pada awal penelitian berkisar antara 7,99-8,09; dan pada akhir penelitian berkisar antara 7,89-8,08. Nilai $\mathrm{pH}$ pada semua perlakuan masih berada pada kisaran $\mathrm{pH}$ optimal, yaitu 7,5-8,5 (Poernomo, 1988). Nilai pH yang tinggi dapat meningkatkan kadar $\mathrm{NH}_{3}$ yang secara tidak langsung membahayakan kehidupan udang.

Oksigen terlarut (DO) pada awal penelitian berkisar antara 6,22-6,94 mg/L, dan pada akhir penelitian berkisar antara 6,05-6,38 mg/L. Nilai DO selama penelitian cukup baik untuk pemeliharaan larva udang windu. Pada saat oksigen terlarut $<2 \mathrm{mg} / \mathrm{L}$, udang akan mengalami stress dan akan mengalami kematian apabila diekspose pada perairan dengan kandungan oksigen terlarut $<1 \mathrm{mg} / \mathrm{L}$ selama beberapa jam (Boyd, 1982).

Nitrit $\left(\mathrm{NO}_{2}\right)$ pada awal penelitian berkisar antara 0,152-1,366 mg/L, sedangkan pada akhir penelitian berkisar antara 2,08-2,53 $\mathrm{mg} / \mathrm{L}$. Kadar nitrit yang aman bagi pertumbuhan udang sebaiknya tidak lebih dari $4,5 \mathrm{mg} / \mathrm{L}$.
Konsentrasi nitrit yang mematikan 50\% populasi udang windu ( $\left(\mathrm{LC}_{50}\right)$ adalah $45 \mathrm{mg} / \mathrm{L}$ dalam waktu 96 jam (Boyd, 1990).

Amonia $\left(\mathrm{NH}_{3}\right)$ pada awal penelitian berkisar antara 0,052-0,084 $\mathrm{mg} / \mathrm{L}$, sedangkan pada akhir penelitian berkisar antara 0,060-0,1 07 $\mathrm{mg} / \mathrm{L}$. Peningkatan kandungan amonia pada akhir penelitian dibandingkan kandungan amonia pada awal penelitian disebabkan adanya sisa metabolisme dan bahan organik tersuspensi. Namun, kandungan amonia pada semua perlakuan selama penelitian masih berada di bawah 0,4 mg/L; yang menurut Boyd (1982), merupakan batas kritis penyebab kematian bagi udang.

\section{KESIMPULAN}

Isolat $U_{a}$ dan $9_{a}$ yang masing-masing diisolasi dari saluran pencernaan udang vaname dan Cyclotella efektif menghambat pertumbuhan $V$. harveyi serta secara signifikan dapat meningkatkan sintasan larva udang windu. Nilai sintasan larva udang pada perlakuan yang selain diinfeksi $V$. harveyi MR5339 juga ditambahkan isolat Ua dan 9a adalah 88,3\%; berbeda nyata dengan kontrol positif yang hanya diinfeksi $V$. harveyi MR5339 (65\%).

\section{DAFTAR ACUAN}

Alabi, A.O., Jones, D.A., \& Latchford, J.W. 1999. The efficacy of immersion as opposed to oral vaccination of Penaeus indicus larvae against Vibrio harveyi. Aquaculture, 179: 111. 
Boyd, C.E. 1982. Water Quality Management for Pond Fish Culture. Elsevier Scientific Publishing Company, Amsterdam, the Netherlands, $318 \mathrm{pp}$.

Boyd, C.E. 1990. Water Quality in Pond for Aquaculture. Alabama Agricultural Experiment Station, Auburn University, Alabama, Birmingham Publishing Co USA, 482 pp.

Douillet, P.A. \& Langdon, C.J. 1994. Use of a probiotics for the culture of larvae of the Pacific Oyster (Crassostrea gigas Thunberg). Aquaculture, 1 19: 25-40.

Effendie, M.I. 1979. Metode Biologi Perikanan. Yayasan Dewi Sri. Bogor, 105 hlm.

Fuller, R. 1992. History and Development of Probiotics. Di dalam: Fuller R, editor. Probiotics the Scientific Basis. London: Chapman and Hall, p. 1-8.

Gomez-Gil, B, Roque, A., \& Tumbull, J.F. 2000. The use and selection of probiotic bacteria for use in the culture of larval aquatic organisms. Aquaculture, 191: 259-270.

Gram, L., Melchiorsen, J., Spanggaard, B., Huber, I., \& Nielsen, T.F. 1999. Inhibition of Vibrio anguillarum by Pseudomonas fluorescens $\mathrm{AH} 2$, a possible probiotic treatment of fish. Appl Environ Microbiol., 65: 969-973.

Huisman, E.A. 1987. Principles of Fish Production. Department of Fish Culture and Fisheries. Wageningen Agricultural University. Netherlands, 170 pp.

Haryanti, Sugama, K., Tsumura, S., \& Nishijima, T. 2000. Potentiality of bacteria isolated from seawater as biological control agent for vibriosis in black tiger shrimp Penaeus monodon larvae. Dalam: Hardjito, L. (Ed.). Proceedings of International Symposium on Marine Biotechnology (ISMB 2000). Center for Coastal and Marine Resources Studies, IPB, Bogor, Indonesia, p. 182-189.

Karunasagar, I., Pai, R., Malathi, G.R., \& Karunasagar, I. 1994. Mass mortality of Penaeus monodon larvae due to antibioticresistant Vibrio harveyi infection. Aquaculture, 128: 203-209.

Lavilla-Pitogo, C.R., Baticados, M.C.L., CruzLacierda, E.R., \& De la Pena, L.D. 1990. Occurrence of luminous bacterial diseases of Penaeus monodon larvae in the Philiphines. Aquaculture, 91: 1-13.

Muliani, Suwanto, A., \& Hala, Y. 2003. Isolasi dan karakterisasi bakteri asal laut Sulawesi untuk biokontrol penyakit vibriosis pada larva udang windu (Penaeus monodon Fab.). Hayati, 10: 6-11.
Ohhira, I., Tamura, T., Fujii, N., Inagaki, K., \& Tanaka, H. 1996. Antimicrobial activity against methicillin-resistant Staphylococcus aureus in the culture broth of Enterococcus faecalis $\mathrm{TH} 10$, an isolate from Malaysian fermentation food, Temph. Japanese J Dairy and Food Sci., 45: 93-96.

Poernomo, A. 1988. Faktor lingkungan dominan pada budidaya udang intensif. HIm. 27-39. Panitia Seminar Usaha Budidaya Udang Tambak di Jawa Timur. Surabaya, 62 hlm.

Rengpipat, S.S., Rukpratanporn, S., Piyatiratitivorakul, S., \& Menaveta, P. 1998a. Probiotic in aquaculture: a case study of probiotics for larvae of black tiger shrimp (Penaeus monodon). In: Flegel, T.W. (Ed.). Advances in Shrimp Biotechnology. Proceedings to the special session on shrimp biotechnology, $5^{\text {th }}$ Asian Fisheries Forum; Chiengmai, Thailand. Bangkok: National Center for Genetic Engineering and Biotechnology, p. 176-181.

Rengpipat, S.S., Rukpratanporn, S., Piyatiratitivorakul, S., \& Menaveta, P. 1998b. Effects of a probiotic bacterium on black tiger shrimp Penaeus monodon survival and growth. Aquaculture, 167: 301-313.

Rengpipat, S.S., Rukpratanporn, S., Piyatiratitivorakul, S., \& Menaveta, P. 2000. Immunity enhancement in black tiger shrimp (Penaeus monodon) by a probiont bacterium (Bacillus S11). Aquaculture, 191: 271-288.

Riquelme C et al. 1997. Potential probiotic strains in the culture of the Chilean scallop Argopecten purpuratus (Lamarck, 1819). Aquaculture, 154: 17-26.

Ruangpan, L. 1998. Luminous bacteria associated with shrimp mortality. Di dalam: Flegel T.W. (Ed.). Advances in Shrimp Biotechnology. Proceedings to the special session on shrimp biotechnology, $5^{\text {th }}$ Asian Fisheries Forum; Chiengmai, Thailand. Bangkok: National Center for Genetic Engineering and Biotechnology. p. 205-211.

Skjermo, J. \& Vadstein, O. 1999. Techniques for microbial control in the intensive rearing of marine larvae. Aquaculture, 177: 333-343.

Suwanto, A., Yuhana, M., Herawaty, E., \& Angka, S.L. 1998. Genetic diversity of luminous Vibrio isolated from shrimp larvae. Di dalam: Flegel T.W. (Ed.). Advances in Shrimp Biotechnology. Proceedings to the special session on shrimp biotechnology, $5^{\text {th }}$ Asian 
Fisheries Forum; Chiengmai, Thailand. Bangkok: National Center for Genetic Engineering and Biotechnology, p. 217-224.

Teo, J.W.P., Suwanto, A., Poh, C.L. 2000. Novel $\beta$-lactamase genes from two environmental isolates of Vibrio harveyi. Antimicrob Agents Chemother, 44: 1,309-1,314.

Tjahjadi, M.R., Angka, S.L., \& Suwanto, A. 1994. Isolation and evaluation of marine bacteria for biocontrol of luminous bacterial diseases in tiger shrimp larvae (Penaeus monodon Fab.). Aspac J Mol Biol Biotechnol, 2: 234-352.

Verschuere, L., Rombaut, G., Sorgeloos, P., \& Verstraete, W. 2000. Probiotic bacteria as biological control agents in aquaculture. Microbiol Mol Biol Rev., 64: 655-671. 